\title{
The Effect of Information Technology Utilization, Management Support, Internal Control, and User Competence on Accounting Information System Quality (Study on Finance Company in Jakarta)
}

\author{
Khristina Damayanti*, Fardinal
}

Magister of Accounting, Postgraduate, University of Mercu Buana

DOI: $10.36348 / \mathrm{sb} .2019 . \mathrm{v} 05 \mathrm{i} 12.009$

| Received: 05.12.2019 | Accepted: 14.12.2019 | Published: 20.12.2019

*Corresponding author: Khristina Damayanti

\section{Abstract}

This research aims to determine the effect of information technology, management support, and internal control on quality of accounting information systems. Research population located in a finance company in Jakarta. The research sample was 137. Data were collected using a questionnaire method with a Likert scale. The data analysis method used is Partial Least Square (PLS).The overall results of this research stated that information technology, management support, internal control affect the quality of accounting information systems. User competence does not affect the quality of accounting information systems. This research has limitations only conducted at finance companies. Therefore, it is better for further research to be done in different companies and add or expand other variables that can affect the quality of accounting information systems.

Keywords: Information Technology Utilization, Management Support, Internal Control, User Competence, Accounting Information System Quality, Finance Company.

Copyright @ 2019: This is an open-access article distributed under the terms of the Creative Commons Attribution license which permits unrestricted use, distribution, and reproduction in any medium for non-commercial use (NonCommercial, or CC-BY-NC) provided the original author and source are credited.

\section{INTRODUCTION}

Information data are useless if they do not have quality. Quality accounting information is obtained from the result of quality accounting information system implementation [1]. The fundamental role of accounting information system in an organization is to result in quality accounting information [2]. Quality accounting information is useful to help the users in making beneficial decisions [3]. In addition, it will also result quality business management.

A quality information system is usually flexible, efficient, accessible, and timely [4]. Along with Ralph and George, De Lone and McLean explain that quality information system is usually flexible, efficient, accessible and timely) [5]. Besides, Ong et al. [5] state that to assess quality information system, it can use dimensions of Reliability, Flexibility, Integration, Accessibility and Timeliness. Laudon and Laudon add that an information system that blends technical efficiency with sensitivity to organizational and human needs, leading to higher job satisfaction and productivity [6].

However, in fact, quality accounting information system is not completely implemented by companies in Indonesia. The phenomenon that happens in Indonesia are the state financial report and business entreprise cannot be made as the guide to know and to anticipate the situation and become the base in making decision [7] even the bad quality of accounting information resulted makes the financial report lose its trustworthiness value [8].

The similar phenomenon explained by Azhar Susanto [9], that accounting standard still cannot be utilized yet because of the company's external or internal factors; such as caused by the human resource in accounting department of a company still cannot perform it well due to several causes like honesty issue in which he/she deliberately manipulates data and the accounting process for personal, community or company benefits. 
The other thing explained by Azhar Susanto [2] is that mostly accounting system implemented in the industry era is done manually. Some companies still use mechanical equipment and electricity while some other companies have been using computer as the data processing tool (EDP) in order that the speed and the processing become better. In Indonesia, the use of computer in processing accounting data is called accounting computer in which probably this term is not known scientifically (internationally). Accouting data process by using computer is commonly done partially or not integrated completely. Even if they use network, only computer that is integrated and its strogare media is saved in the server. For this, they ofte call it as collective dataset or data bank.

The utilization of information technology towards accounting information system is positive and in line. It means that the better the utilization of information technology, the better quality accouting information system resulted [9]. Therefore, the utilization of information technology plays a significant role in resulting quality accounting information system because it is always related to the use of computer technology and other technologies used to process information.

Besides the utilization of information technology, the thing that needs to be paid attention by the company to obtain quality accounting information system is top management support. Astuty [10] expresses that top management is the highest management level in an organization which is responsible for all organization activities. The terms for those who have high position in the top management are: director, president director, direction board, and so forth.

According to Reddy [11], top management should be involved during design and implementation phases to ensure the system acceptance. Without full commitment from the top management, the possibility of system success will be low [11]. The presence and the role of accounting manager who has wide knowledge in arts are one of the factors that influence accounting information system quality and the support from top management [12]. The support from top management will be significant if the top management also has power and influence to socialize the development of information system that enables users to participate in the system development [13]. The research conducted by [14] shows that accounting information system can be improved by the support of top management. It is explained that top management is highly essential in the organization in formulating policy, procedure, and supervision on the accounting information system used to protect organization's assets from loss or fraud to ensure the accuracy and the records reliability as well as the accounting reports.
Knowledge, user experience, management, and information system people are responsible for contribution towards successful accounting information system in the organization.

The implementation of internal control in accounting information system is important. Romney and Steinbart [15] state that accounting information system with right internal control structure is organization plan and business method used to keep the asset, provide accurate and reliable information, encourage and fix the efficiency of organization, and support the compatibility with the policy that has been implemented.

Internal control is designed to ensure the accuracy of data entry, processing technique, saving method, and information accuracy. Internal control system is designed to monitor and to Pengendalian internal dirancang untuk menjamin ketepatan entri data, teknik-teknik pengolahan, maintain quality and security from accounting information system actibity to conduct, input, process, and output activities [16]. Developing internal control in computer-based accounting information system will help the attempt of management to protect the company's assets from losses and embezzlement as well as to keep data accuracy of company's finance [17]. From the previous research result done by [18], it is explained that if the effect of internal control system is there on accounting information system quality, it will make the internal implementation better. It means that it will give effect on the accounting information system quality improvement. Besides, if the internal control is bad, it will make the accounting information system decreased.

User competence in using accounting information system can be seen from the user's ability in receiving data, processing data, and applying data. The user competence should be adjusted to the technology difficulty level used. If the technology used has high difficulty level, the user competence needed should also have better quality. To improve the quality of user competence, it is necessary to conduct special education training and others.

Tissya Chayatunnufus [10] states that user competence gives strong effect on the implementation of accounting information system in which the better user competence, the better quality the accounting information system implementation will be. User competence is ability, skill, and strength of a person related to intellectual competence and physical competence to perform his works [18] also conclude that user competence gives significant effect on accounting information system which means that the user who is more competent will improve quality accounting information system. 
This research is the development from the previous research conducted by [18] regarding the effect of user competence and internal control towards accounting information system quality. The difference between this research and the previous research is the research location and the number of independent variable. The previous research conducted the research at Shariah Bank in Bandung, while the present researcher conducted this research in Finance Company in Jakarta. In addition, the previous research conducted the research by using two independent variables namely the utilization of information technology and the implementation of internal control. On the other hand, the present researcher added two independent variables so that there are four independent variables namely the information technology utilization, management support, internal control, and user competence.

Based on the background explained aforementioned, the researcher conducts the research entitled with "The Effect of Information Technology, Management Support, Internal Control, and User Competence on Accounting Information System Quality (Survey on Finance Company in Jakarta)."

\section{REVIEW OF RELATED LITERATURE Information Technology Utilization}

According to Thompson et al. [19] cited in Wijana [20], it is expressed that the utilization of information technology is the benefit expected by the information system users in performing their works or behavior in using technology when performing works. The measurement is based on the tensity of utilization, the frequency of utilization, and the number of application or software used.

\section{Management Support}

According to Reddy [11], top management should be involved during design and implementation phases to ensure the system acceptance. Without full commitment from the top management, the possibility of system success will be low [11]. The presence and the role of accounting manager who has wide knowledge in arts are one of the factors that influence accounting information system quality and the support from top management [12]. The support from top management will be significant if the top management also has power and influence to socialize the development of information system that enables users to participate in the system development [13].

\section{Internal Control}

The implementation of internal control becomes one of the factors that influence accounting information system quality. Internal control is needed as the guide or the limitation implemented by the company to minimize the risks that may occur related to the use of accounting information system to achieve the goals of the company [21].
The implementation of internal control in accounting information system is important. Romney and Steinbart [15] state that accounting information system with right internal control structure is organization plan and business method used to keep the asset, provide accurate and reliable information, encourage and enhance the efficiency of organization, and support the compatibility with the policy that has been implemented.

\section{User Competence}

User competence in using accounting information system can be seen from the user's ability in receiving data, processing data, and applying data. The user competence should be adjusted to the technology difficulty level used. If the technology used has high difficulty level, the user competence needed should also have better quality. To improve the quality of user competence, it is necessary to conduct special education training and others.

\section{Accounting Information System Quality}

Information data are useless if they do not have quality. Quality accounting information is obtained from the result of quality accounting information system implementation [1]. The fundamental role of accounting information system in an organization is to result in quality accounting information [17]. Quality accounting information is useful to help the users in making beneficial decisions [3]. In addition, it will also result quality business management.

A quality information system is usually flexible, efficient, accessible, and timely [4]. Along with Ralph and George, De Lone and McLean explain that quality information system is usually flexible, efficient, accessible and timely) [5]. Besides, Ong et al. [16] state that to assess quality information system, it can use dimensions of Reliability, Flexibility, Integration, Accessibility and Timeliness. Laudon and Laudon add that an information system that blends technical efficiency with sensitivity to organizational and human needs, leading to higher job satisfaction and productivity [6].

\section{HYPHOTHESIS}

The Effect of Information Technology Utilization on Accounting Information System Quality

The utilization of information technology towards accounting information system is positive and in line. It means that the better the utilization of information technology, the better quality accouting information system resulted [9]. Therefore, the utilization of information technology plays a significant role in resulting quality accounting information system because it is always related to the use of computer technology and other technologies used to process information. 
H1: Information Technology Utilization Gives Positive Effect on Accounting Information System Quality

\section{The Effect of Management Support on Accounting Information System Quality}

The support from top management will be significant if the top management also has power and influence to socialize the development of information system that enables users to participate in the system development [13]. The research conducted by [14] shows that accounting information system can be improved by the support of top management. It is explained that top management is highly essential in the organization in formulating policy, procedure, and supervision on the accounting information system used to protect organization's assets from loss or fraud to ensure the accuracy and the records reliability as well as the accounting reports.

H2: Management Support Gives Positive Effect on Accounting Information System Quality

\section{The Effect of Internal Control on Accounting Information System Quality}

Internal control is designed to ensure the accuracy of data entry, processing technique, saving method, and information accuracy. Internal control system is designed to monitor and to maintain quality and security from accounting information system actibity to conduct, input, process, and output activities [16]. Developing internal control in computer-based accounting information system will help the attempt of management to protect the company's assets from losses and embezzlement as well as to keep data accuracy of company's finance [17]. In order that the accounting information system functions as in accordance with what is expected to achieve goals needed by management, internal control is essentialy required [2].

H3: Internal Control Internal Gives Positive Effect on Accounting Information System Quality

\section{The Effect of User Competence on Accounting Information System Quality \\ User competence in using accounting} information system can be seen from the user's ability in receiving data, processing data, and applying data. The user competence should be adjusted to the technology difficulty level used. If the technology used has high difficulty level, the user competence needed should also have better quality. To improve the quality of user competence, it is necessary to conduct special education training and others.

H4: User Competence Gives Positive Effect on Accounting Information System Quality

\section{RESEARCH METHOD Research Method}

In this research, the researcher uses quantitative research in which the process of obtaining information is expressed in form of numbers as the tool to find the information regarding what is known. Quantitative research method is a research method which is based on positivism philosophy used to study particular population or sample. The sampling technique is commonly done randomly. In addition, the data collection uses research instruments; the data analysis is quantitative with the purpose of examining the hypotheses that have been determined.

\section{Varible Operationalization}

Variable operationalization in research is regarding the effect of information technology utilization, management support, internal control, and user competence on accounting information system quality (survey on finance company in Jakarta).

\section{Research Population and Sample}

Kasmadi and sunariah [22] state that population is all data that becomes the researcher's attention in a coverage and time that have been determined. The research population is the universum of research objects that may be in form of human, animal, plant, air, symptom, event, life attitude, and so forth [23].

The population used in this research is Finance Company registered in Financial Services Authority in Special Capital Region of Jakarta of 168 companies. The finance companies registered in Financial Services Authority are obliged to submit their financial report timely every month through Information System of Finance Company Report.

\section{Research Sample}

Sample is a procedure of data collection in which it is only a part of population taken and used to determine the nature and the characteristics needed from a population [23]. The sample in this research is determined by using Slovin formula.

The sampling technique used is simple random sampling which is a sampling from a population by particular way so that every population member has a chance to be chosen or to be taken. The samples are 24 companies. 


\section{RESULTS AND DISCUSSION} Validity Test (Outer Model)

Based on the output from SmartPLS, the value of loading factor from all indicator has fulfilled convergent validity which is more than 0.7 and all loading factor indicators value with its dimension is higher than the loading factor value between indicator and other dimensions which means that it also has fulfilled discriminant validity so that all indicators in this research is valid.

\section{Reliability Test (Outer Model)}

Based on the output from SmartPLS, all research variables has composite reliability above 0.6 and cronbach's alpha above 0.7 so that it can be concluded that the indicators used in each variable has good reliability or is able to measure its construct.

\section{Coefficient Determination Test $\left(\mathbf{R}^{2}\right)$ (Inner Model)}

Based on the output from SmartPLS, the value of $\mathrm{R}^{2}$ of taxpayer compliance level is of 0.923 or $92.3 \%$. It means that all independent variables namely Information Technology Utilization, Top Management Support, Internal Control Effectiveness, and User Competence are of $92.3 \%$ on information system quality as the independent variable, whilt the remaining $7.7 \%$ is the contribution from other variables which are not discussed in this research.

\section{Structural Path Coefficient Significance Test (Inner Model)}

Path coefficient obtained from the variable of information technology utilization towards accounting information system quality is of 0.314 with the value of t-statistics $3.863>1.96$. It means that the information technology utilization gives positive and significant effect on accounting information system quality. The higher information technology utilization, the more improving the accounting information system quality will be. The result of this research supports hypothesis one (H1) that information technology utilization gives positive effect on information sistem quality.

Path coefficient obtained from the variable of management support towards accounting information system quality is of 0.231 with the value of t-statistics is $2.919>1.96$. It means that management support gives positive and significant effect on accounting information system quality. The greater the top management support, the better the accounting information system quality. The result of this research supports hypothesis two $(\mathrm{H} 1)$ that management support gives positive effect on information sistem quality.

Path coefficient obtained from the variable of internal control implementation towards accounting information system quality is of 0.507 with the value of t-statistics is $6.486>1.96$. It means that internal control gives positive and significant effect on accounting information system quality. The greater the internal control, the better the accounting information system quality. The result of this research supports hypothesis three (H1) that internal control implementation gives positive effect on information sistem quality.

Path coefficient obtained from the variable of user competence towards accounting information system quality is of -0.045 with the value of t-statistics is $0.937<1.96$. It means that user competence gives positive and significant effect on accounting information system quality. Accounting information system quality will be greater if the employees have more specialization ability than general ability. The result of this research does not support hypothesis four (H4) that user competence does not give positive effect on accounting information system quality.

\section{DISCUSSION}

Based on the result of statistics test, it is known that information technology utilization gives positive and significant effect on accounting information system quality. It means that every improvement of information system implementation will improve accounting information system quality. As it is known that the implementation of accounting information system is done with the purpose to minimize misinformation obtained and to provide accurate and relevant information so that it can help the employee's work. From the research result, it is proven that information technology utilization affects information system quality so that it generates accurate and efficient information so that it can minimize uncertainty in decision making.

Based on the results of statistics test and significant, it is known that management support gives effect on accounting information system quality. It means that there is a significant effect from top management support towards accounting information system quality. Therefore, hypothesis 2 is fulfilled. Therefore, it can be interpreted that the higher the management support, the more improving accounting 
Khristina Damayanti \& Fardinal., Sch Bull, Dec 2019; 5(12): 753-761

information system quality. Top management support is the important factor in determining the effectiveness of information system reception in a company. The support given by top management in the development or the use of accounting information system done by employees can improve the effectiveness of accounting information system of the company. On the other hand, top management support also reflects that the manager has involvement in the system operation done by the employees which means that the better the support from top management, the better accounting information quality obtained.

Based on the results of statistics test and significance, it is known that the implementation of internal control gives effect on accounting information system quality. Hence, hypothesis 3 is fulfilled. The coefficient obtained is positive which is 0.507 . Therefore, it can be stated that the better the internal control effectiveness, the better the accounting information system quality. Accounting information system is designed by the company to process and to save transaction data so that it obtains timely, accurate, and reliable information. Accounting information becomes one of the important factors in making a decision. To obtain right and accurate information, company's internal control that runs effectively is needed. The better the internal control effectiveness of a company, the better the accounting information system quality will be.

Based on the results of statistics test and significance, it is known that user competence does not give effect on accounting information system quality. The value of $\mathrm{T}$ statistics on the effect of user competence towards accounting information system quality is of 0.937 with the p-value is of 0.349 . The result of the test shows that the value of $\mathrm{T}$ statistics < 1.96 and $p$-value $>0.05$. It means that there is no significant effect of User Competence on Accounting Information System Quality. Therefore, hypothesis 4 is not fulfilled.

Table

Table-1: R-Square

\begin{tabular}{|c|c|}
\hline Variabel & $\begin{array}{c}\text { R } \\
\text { Square }\end{array}$ \\
\hline $\begin{array}{l}\text { Quality of Accounting } \\
\text { Information Systems (Y) }\end{array}$ & 0,925 \\
\hline
\end{tabular}

Table-2: Path Coefficient Value and T-statistik

\begin{tabular}{|l|c|c|c|}
\hline $\begin{array}{l}\text { Relations between } \\
\text { Variables }\end{array}$ & $\begin{array}{c}\text { Path } \\
\text { Coefficient }\end{array}$ & t-statistik & P Value \\
\hline Utilization of & 0,314 & 3,863 & 0,000 \\
$\begin{array}{l}\text { Information } \\
\text { Technology } \rightarrow \\
\text { Quality of } \\
\text { Accounting } \\
\text { Information Systems }\end{array}$ & & & \\
\hline $\begin{array}{l}\text { Top Management } \\
\text { Support } \rightarrow \text { Quality of } \\
\text { Accounting } \\
\text { Information Systems }\end{array}$ & 0,231 & 2,919 & 0,004 \\
\hline $\begin{array}{l}\text { Efectivity Internal } \\
\text { Control } \rightarrow \text { Quality of } \\
\text { Accounting } \\
\text { Information Systems }\end{array}$ & 0,507 & 6,486 & 0,000 \\
\hline $\begin{array}{l}\text { User Competency } \rightarrow \\
\text { Quality } \\
\text { Accounting of } \\
\text { Information Systems }\end{array}$ & $-0,045$ & 0,937 & 0,349 \\
\hline
\end{tabular}

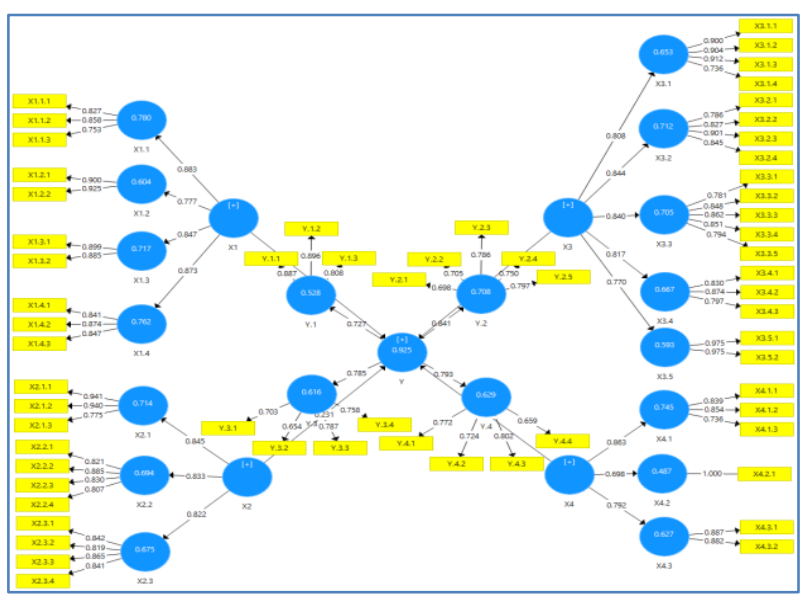

Picture-1: Result of loading research

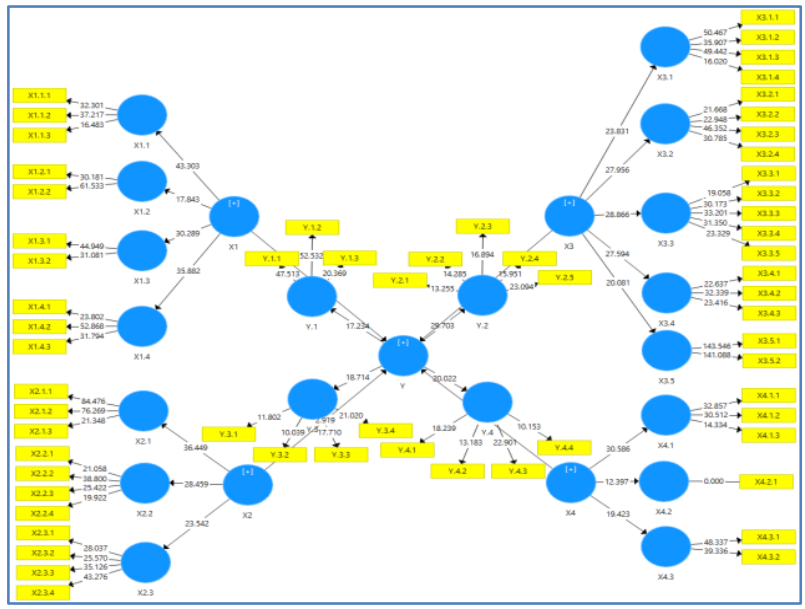

Picture-2: Result of Inner Model

\section{SUGGESTION AND CONCLUSION Conclusion}

\section{Based on the results of explanation above, it can be} concluded that:

- Utilization of Information Technology has a significant and positive effect on the Quality of 
Accounting Information Systems. Thus hypothesis 1 is fulfilled. More higher Utilization of Information Technology it tends to improve the Quality of Accounting Information Systems.

- Top Management Support has significant and positive effect on the Quality of Accounting Information Systems. Thus hypothesis 2 is fulfilled. More higher Top Management Support it tends to improve the Quality of Accounting Information Systems.

- Internal Control has a significant and positive effect on the Quality of Accounting Information Systems. Thus hypothesis 3 is fulfilled. Higher Internal Control it tends to improve the Quality of Accounting Information Systems.

- User Competency has no significant effect on the Quality of Accounting Information Systems. Thus hypothesis 4 is not fulfilled.

\section{Suggestion}

Based on the discussion result and the conclusion above, the researcher gives suggestions as follows:

\section{For Company}

- The implementation of accounting information system that has been doing should be maintained and improved in order that there is no system change anymore that hampers the company performance. Thus, the reports related to finance and non-finance has better quality.

- The company is better to improve the quality of training system and seminar for employees periodically so that if there is something wrong on software, it can be prevented as early as possible and it can be handled immediately. Therefore, the use of information system can be optimal and can improve accounting information system quality in the company.

- For user competence which is still weak especially in terms of knowledge, motive, and skill: it is better to understand the working system systematically and the technology used. Thereofre, it is necessary to provide continuous trainin related to the use of technology and training in evaluating data accuracy to improve user competence or to improve human resource. Besides, for internal control which is still weak especially in terms of risk assessment, control activity, information and communication, it is necessary to conduct risk assessment periodically, to enhance general control and applicaito control such as management control that covers function distribution, software control, data entry and program control, input and output control, and data process processing control.

\section{For Future Researchers}

For other parties who are willing to study this topic deeper, it is suggested to develop it by selecting different company type and by adding other variables that can affect accounting information system quality.

\section{REFERENCE}

1. Sačer, I. M., Žager, K., \& Tušek, B. (2006, January). Accounting information system's quality as the ground for quality business reporting. In IADIS International conference, e-commerce 2006.

2. Susanto, A. (2017). Sistem informasi akuntansi: pemahaman konsep secara terpadu.

3. Hall, J. A. (2008). Accounting Information Systems, South-Western Cengage Learning.

4. Stair, R., \& Reynolds, G. (2006). Fundamentals of Information Systems, 3rd/4th Edition, Thomson.

5. DeLone, W.H., \& Mclean, E.R. (2003). The DeLone McLean. Model of Information System Success: A Ten-Year Update.Journal of Management Information, 19(4):9:30.

6. Laudon., Kenneth, C., dan Jane P. Laudon. (2007). Sistem Informasi Manajemen. Penerjemah Chriswan Sungkono dan Machmudin Eka P. Jakarta: Salemba Empat

7. Nasution, A. (2011). Peranan BPK dalam Mewujudkan Transparansi Fiskal dan Pembangunan Sistem Sosial Indonesia.

8. Purnomo, H. (2012). Majority of Local Government Financial Statements Needs Improvement. Surabaya: TEMPO Interaktif.

9. Azhar S. (2016). The Effect of Internal Control on Accounting Information System. International bussines Management, Medwell Journals.

10. Romney, M.B., dan Paul, J.S. (2015). Accounting Information sytestm, 13th ed. England: Pearson Educational Limited.

11. Bidgoli, H. (2004). The Internet Encyclopedia Vol 2. USA: John Wiley \& Sons, Inc.

12. Komala, A. R. (2012). The influence of the accounting managers' knowledge AND the top managements' support on the accounting information system and its impact on the quality of accounting information: A case of zakat institutions in Bandung. Journal of Global Management, 4(1), 53-73.

13. Putranto, A., \& Chen, X. D. (2014). A simple and effective model for modeling of convective drying of sewage sludge: the reaction engineering approach (REA). Procedia Chemistry, 9, 77-87.

14. Mkonya, V. L., Jintian, Y., Nanthuru, S. B., \& Jinyevu, S. A. (2018). Analysis of Top Management Support and Individual Factors Influence on Accounting Information System and its Impact on the Accounting Information Quality for Projects. International Journal of Management Science and Business Administration, 4(3), 19-29. 
15. Romney, M. B., \& Steinbart, P. J. (2006). Sistem Informasi Akuntansi, Terjemahan.

16. O'Brien, J.A., dan Marakas. (2010). Management System Information. McGraw Hill, New York.

17. Ratnam, R., Jones, D. L., Wheeler, B. C., O’Brien Jr, W. D., Lansing, C. R., \& Feng, A. S. (2003). Blind estimation of reverberation time. The Journal of the Acoustical Society of America, 114(5), 28772892.

18. Isti, Astria, E. (2017). Pengaruh Kompetensi Pengguna dan pengendalian Internal terhadap Kualitas sistem informasi Akuntansi (Survey pada bank syarian di Bandung). Prosiding Akuntansi Universitas Islam Bandung, 3(2).

19. Thompson, W. J. (1991). Cyclic nucleotide phosphodiesterases: pharmacology, biochemistry and function. Pharmacology \& therapeutics, 51(1), 13-33.

20. Wijana, N. (2007). Pemanfaatan Teknologi Informasi dan pengaruhnya pada kinerja individual pada bank perkreditan rakyat di kabupaten tabanan. Jurnal. Universitas Udayana.

21. Aviana, S., \& Mega, P. (2012). Penerapan pengendalian internal dalam sistem informasi akuntansi berbasis komputer. Jurnal Ilmiah Mahasiswa Akuntansi, 1(4), 65-70.

22. Kasmadi., \& Sunariah. (2013). Panduan Modern Penelitian Kuantitatif. Bandung: Alfabeta

23. Siregar, S. (2013). Metode Penelitian Kuantitatif. Jakarta: PT Fajar Interpratama Mandiri. 